\title{
Chapter 31 \\ Conclusions and Future Directions \\ for Academic Integrity in Canada
}

\author{
Sarah Elaine Eaton (D) and Julia Christensen Hughes (i)
}

\begin{abstract}
In the conclusion to this edited volume, we highlight key themes from the book, making reference to the particular chapters that address them. We discuss the symbolic importance of the work by situating previous work and celebrating milestones related to academic integrity in Canada. We acknowledge the limitations of the book and offer recommendations for future directions for research, practice, and policy.
\end{abstract}

We chose the title of this volume, "Academic Integrity in Canada: An Enduring and Essential Challenge" (Eaton \& Christensen Hughes, eds., 2022) intentionally. Contributors from across the country have shared new perspectives on enduring problems, but do so in a way that has been uniquely and exclusively Canadian. Contributors also bring new insights on important and essential topics, such as Indigenous perspectives on academic integrity (see Lindstrom, 2022; Poitras Pratt \& Gladue, 2022) that until now, have not been part of the broader discourse.

\section{Symbolic Importance of this Volume: Situating Previous Work and Celebrating Milestones}

This book began with the idea of marking the fifteenth anniversary of the seminal articles by Julia Christensen Hughes and Donald (Don) McCabe (2006a, b) and demonstrating how far Canada has come since this work was published. Despite Christensen Hughes and McCabe's work receiving extensive media attention and even an award from the Canadian Journal of Higher Education for the year it was

\author{
S. E. Eaton $(\varangle)$ \\ University of Calgary, Calgary, AB T2N 1N4, Canada \\ e-mail: seaton@ucalgary.ca \\ J. Christensen Hughes \\ Yorkville University, Toronto, ON M4Y 1W9, Canada
}

(C) The Author(s) 2022

S. E. Eaton and J. Christensen Hughes (eds.), Academic Integrity in Canada,

Ethics and Integrity in Educational Contexts 1 ,

https://doi.org/10.1007/978-3-030-83255-1_31 
published (see Christensen Hughes \& Eaton, 2022b), it remained, for many years, the only major study on the topic in Canada.

As research on educational integrity was flourishing in other countries, Canada lagged behind (see Eaton \& Edino, 2018). Canadians working in the field of academic integrity often found themselves turning to research and guidance from other countries and attempting to apply those findings to our own context. Although transferring findings from elsewhere can be helpful to an extent, such applications are limited in many ways. Even in the widely referenced Handbook of Academic Integrity (Bretag, ed., 2016), a volume spanning more than 1000 pages, there was one chapter that included a focus on Canada, and even then it was done in comparison with another country (see Foeger \& Zimmerman, 2016). Although there were other contributors to the handbook who were Canadian (see: Christensen Hughes \& Bertram Gallant, 2016; Newton \& Lang, 2016; Rogerson \& Basanta, 2016), there were no chapters exclusively about Canada.

This book showcases how far Canadians have come in terms of their contributions to the field in the fifteen years since Christensen Hughes \& McCabe (2006a, b) published their work. It also highlights unique aspects of the Canadian higher education context. In doing so, it demonstrates how far we have come in the five years since the internationally acclaimed Handbook on Academic Integrity was published (Bretag, 2016).

\section{The Significance of Contributions in This Volume}

In this volume, contributors share empirical findings (see deMontigny, 2022; Garwood, 2022; Hamilton \& Wolsky, 2022; McNeill, 2022; Packalen \& Rowbotham, 2022; Peters et al., 2022; Rossi, 2022), as well as conceptual and other forms of scholarly expertise and insights (see Christensen Hughes, 2022; Christensen Hughes \& Eaton, 2022a, b; Crossman, 2022; Eaton \& Christensen Hughes, 2022; Foxe et al., 2022; Hunter \& Kier, 2022, Miron, 2022; Teymouri et al., 2022, Watson Hamilton, 2022) and perspectives from leadership and professional practice (see Kenny \& Eaton, 2022; Morrison \& Zachariah, 2022; Morrow, 2022; Penaluna \& Ross, 2022; Thacker \& McKenzie, 2022). Of particular note are the chapters that broaden understanding of academic integrity beyond the questionable behaviours of students, to include that of faculty, administrators and the history and cultures of institutions of higher learning, as well as those that extend the dialogue around the Scholarship of Teaching and Learning (SoTL) (see Bens, 2022; Kenny \& Eaton, 2022; Hamilton \& Wolsky, 2022), signalling that academic integrity inquiry can fit within SoTL when the focus is on learning and teaching.

This book builds on previous scholarship in the field, but also brings new insights on topics that have previously received limited or no treatment in the literature. For example, to the best of our knowledge, this is the first time Indigenous voices have been included in scholarly discourse on academic integrity (Lindstrom, 2022; Poitras Pratt \& Gladue, 2022). Similarly, although restorative practices have been 
discussed as one approach to addressing breaches of integrity, Sopcak and Hood's (2022) chapter brings new depth to the discussion. We also know that academic integrity at the K-12 level has received inadequate treatment, which Stoesz (2022) addresses in her chapter.

Brenna Clark Gray (2022) addresses questions around the ethics of educational technology, signalling that educators, policy makers and others must pay attention to the ways in which technology will continue to shape education and the ethical complexities that will no doubt bring. Eaton (2022a) presents a historical account of contract cheating in Canada going back more than half a century. These contributions are essential, given the dramatic shift to on-line learning and assessment, as well as the increasingly brazen behaviour of contract cheating companies that have flourished in Canada, becoming billion dollar businesses.

\section{Limitations and Future Directions}

As with any book, ours is not without its limitations. We recognize that although Indigenous contributors have begun an important dialogue about the need to decolonize and Indigenize academic integrity and approaches to educational ethics broadly, the voices of Indigenous scholars included in this volume are from Western Canada. We know that First Nations, Inuit, and Métis peoples are not a singular monolithic group. We recognize the need to extend the dialogue about how to decolonize ethics and integrity in educational contexts further and engage with others from historically marginalized groups; we see the chapters in this book by Poitras Pratt and Gladue (2022) and Lindstrom (2022) as a starting point, not an end.

As contributors were in the early stages of drafting their chapters in 2020, we heard news of George Floyd's murder in Minneapolis (see Hill et al., 2020) and subsequent news stories of continued racism against Black people and other persons of colour. These occurrences are not limited to the United States, and also happen in Canada and elsewhere. During this time period, the Alberta Council on Academic Integrity (2020) released its Statement Against Racism in Matters Relating to Academic Integrity and others began advancing the dialogue about equity, diversity and inclusion as they relate specifically to academic integrity (see Boisvert et al., 2020; Eaton, 2020; Parnther, 2020); we have yet to fully address the ways in which minoritized students are overrepresented in the reporting of misconduct behaviours or sanctioned differently from White peers. These are important topics that must continue to be addressed through research, policy, practice, and advocacy.

We recognize the invaluable role that higher education professionals play in contributing to cultures of integrity and to the learning supports for students. We are delighted to have chapters that include perspectives from those working in academic integrity offices, student affairs, the library, academic writing centres, quality assurance and other non-academic units within learning institutions (see, for example, Bens, 2022; Foxe et al., 2022; Garwood, 2022; Gray, 2022; Morrow, 2022; Penaluna \& Ross, 2022; Sopcak \& Hood, 2022; Rossi, 2022; and Thacker \& McKenzie, 2022). 
We know that the voices of higher education professionals and practitioners deserve to be further elevated and amplified and we encourage more knowledge sharing from those who work in non-academic units.

Although the contributors to this volume represent many provinces of Canada, we recognize that not all regions are represented, such as those from the northern territories or the Atlantic provinces. This is both a limitation and an opportunity. As work on ethics and integrity in Canadian educational contexts continues to develop, it is essential to extend the dialogue to all regions of the country.

We acknowledge topics that we have not fully addressed in this volume that merit further inquiry such as engaging students as partners in academic integrity, as well as the ways machine learning and artificial intelligence are rapidly changing how we learn and teach. These omissions are also opportunities and there is no doubt in our minds that Canadians will continue to contribute to the knowledge base of ethics and integrity in educational contexts over time.

\section{Concluding Remarks}

Canadians are no longer obliged to rely on research from other countries to try and understand academic ethics and integrity in our own country. This volume provides a robust compendium of evidence of research, scholarship, and professional practice about academic integrity in Canada that not only showcases new and original thinking, but provides a base for future research, as well as policy and practice development. The chapters also contribute to the growing body of global scholarship on educational integrity, and provide substantive content that may be relevant to readers in other countries.

\section{References}

Alberta Council on Academic Integrity (ACAI). (2020). Statement Against Racism in Matters Relating to Academic Integrity. https://albertaacademicintegrity.files.wordpress.com/2020/06/ alberta-council-on-academic-integrity-statement-against-racism-2020-06-04.pdf

Bens, S. (2022). Helping students resolve the ambiguous expectations of academic integrity. In: Academic integrity in Canada: An enduring and essential challenge. Springer.

Boisvert, S., Teymouri, N., Medicine Crane, J. A., \& Eaton, S. E. (2020). Exploring Racism and Academic Integrity through a Circle Process. Paper presented at the Alberta Teachers' of English as a Second Language (ATESL) Annual Conference, Online. http://hdl.handle.net/1880/112689

Christensen Hughes, J. (2022). Academic integrity across time and place: Higher education's questionable moral calling. In S. E. Eaton \& J. Christensen Hughes. (Eds.), Academic integrity in Canada: An enduring and essential challenge. Springer.

Christensen Hughes, J., \& Bertram Gallant, T. (2016). Infusing ethics and ethical decision making into the curriculum. In T. Bretag (Ed.), Handbook of academic integrity (pp. 1055-1073). Singapore: Springer Singapore. 
Christensen Hughes, J., \& Eaton, S. E. (2022a). Academic misconduct in Canadian higher education: Beyond student cheating. In S. E. Eaton \& J. Christensen Hughes (Eds.), Academic integrity in Canada: An enduring and essential challenge. Springer.

Christensen Hughes, J., \& Eaton, S. E. (2022b). Student integrity violations in the academy: More than a decade of growing complexity and concern In S. E. Eaton \& J. Christensen Hughes (Eds.), Academic integrity in Canada: An enduring and essential challenge. Springer.

Christensen Hughes, J. M., \& McCabe, D. L. (2006a). Academic misconduct within higher education in Canada. The Canadian Journal of Higher Education, 36(2), 1-21. http://journals.sfu.ca/cjhe/ index.php/cjhe/article/view/183537/183482

Christensen Hughes, J. M., \& McCabe, D. L. (2006b). Understanding academic misconduct. Canadian Journal of Higher Education, 36(1), 49-63. Retrieved from https://journals.sfu.ca/cjhe/index. php/cjhe/article/view/183525

Crossman, K. (2022). Education as a financial transaction: Contract employment and contract cheating. In S. E. Eaton \& J. Christensen Hughes (Eds.), Academic integrity in Canada: An enduring and essential challenge. Springer.

deMontigny, D. (2022). Managing academic integrity in Canadian engineering schools. In S. E. Eaton \& J. Christensen Hughes (Eds.), Academic integrity in Canada: An enduring and essential challenge. Springer.

Eaton, S. E. (2020). Race-based data in student conduct: A call to action. University of Calgary. http://hdl.handle.net/1880/112157.

Eaton, S. E. (2021). Plagiarism in higher education: Tackling tough topics in academic integrity. Santa Barbara, CA: Libraries Unlimited.

Eaton, S. E. (2022). Contract cheating in Canada: A comprehensive overview. In S. E. Eaton \& J. Christensen Hughes (Eds.), Academic integrity in Canada: An enduring and essential challenge. Springer.

Eaton, S. E., \& Christensen Hughes, J. (2022). Academic integrity in Canada: Historical perspectives and current trends. In S. E. Eaton \& J. Christensen Hughes (Eds.), Academic integrity in Canada: An enduring and essential challenge. Springer.

Eaton, S. E., \& Edino, R. I. (2018). Strengthening the research agenda of educational integrity in Canada: A review of the research literature and call to action. International Journal of Educational Integrity, 14(1). https://doi.org/10.1007/s40979-018-0028-7

Foeger, N., \& Zimmerman, S. (2016). Research Integrity: Perspectives from Austria and Canada. In T. Bretag (Ed.), Handbook of academic integrity (pp. 809-821). Singapore: Springer Singapore.

Foxe, J. P., Miller, A., Farrelly, G., Hui, V., Nubla, D., \& Schindler-Lynch, C. (2022). Visual plagiarism: Seeing the forest and the trees. In S. E. Eaton \& J. Christensen Hughes (Eds.), Academic integrity in Canada: An enduring and essential challenge.

Garwood, K. (2022). Supporting academic integrity in the writing centre: Perspectives of student consultants. In S. E. Eaton \& J. Christensen Hughes (Eds.), Academic integrity in Canada: An enduring and essential challenge. Springer.

Gladue, K. (2021). Indigenous Academic Integrity. Calgary, Canada: University of Calgary. Retrieved from https://taylorinstitute.ucalgary.ca/resources/indigenous-academic-integrity

Gray, B. C. (2022). Ethics, ed tech, and the rise of contract cheating. In S. E. Eaton \& J. Christensen Hughes (Eds.), Academic integrity in Canada: An enduring and essential challenge. Springer.

Hamilton, M. J., \& Wolsky, K. L. (2022). The barriers to faculty reporting incidences of academic misconduct at community colleges. In S. E. Eaton \& J. Christensen Hughes (Eds.), Academic integrity in Canada: An enduring and essential challenge: Springer.

Hill, E., Tiefenthäler, A., Triebert, C., Jordan, D., Willis, H., \& Stein, R. (2020). How George Floyd Was Killed in Police Custody. New York Times. https://www.nytimes.com/2020/05/31/us/georgefloyd-investigation.html

Hunter, J., \& Kier, C. A. (2022). Canadian open digital distance education universities and academic integrity. In S. E. Eaton \& J. Christensen Hughes (Eds.), Academic integrity in Canada: An enduring and essential challenge. Springer. 
Kenny, N., \& Eaton, S. E. (2022). Academic integrity through a SoTL lens and 4M framework: An institutional self-study. In S. E. Eaton \& J. Christensen Hughes (Eds.), Academic integrity in Canada: An enduring and essential challenge. Springer.

Lindstrom, G. (2022). Accountability, relationality and Indigenous epistemology: Advancing an Indigenous perspective on academic integrity. In S. E. Eaton \& J. Christensen Hughes (Eds.), Academic integrity in Canada: An enduring and essential challenge. Springer.

McNeill, L. (2022). Changing "hearts" and minds: Pedagogical and institutional practices to foster academic integrity. In S. E. Eaton \& J. Christensen Hughes (Eds.), Academic integrity in Canada: An enduring and essential challenge. Springer.

Miron, J. B. (2022). Academic integrity in work-integrated learning (WIL) settings. In S. E. Eaton \& J. Christensen Hughes (Eds.), Academic integrity in Canada: An enduring and essential challenge. Springer.

Morrison, M., \& Zachariah, P. (2022). Student academic misconduct through a Canadian legal lens. In S. E. Eaton \& J. Christensen Hughes (Eds.), Academic integrity in Canada: An enduring and essential challenge. Springer.

Morrow, L. (2022). Beyond the traditional: academic integrity in Canadian librarianship. In S. E. Eaton \& J. Christensen Hughes (Eds.), Academic integrity in Canada: An enduring and essential challenge. Springer.

Newton, P. M., \& Lang, C. (2016). Custom essay writers, freelancers, and other paid third parties. In T. Bretag (Ed.), Handbook of academic integrity (pp. 249-271). Springer.

Packalen, K., \& Rowbotham, K. (2022). Student insight on academic integrity. In S. E. Eaton \& J. Christensen Hughes (Eds.), Academic integrity in Canada: An enduring and essential challenge. Springer.

Parnther, C. (2020). Creating a Culture of Equity in Academic Integrity: Best Practices for Teaching and Learning. Webinar presented at the Taylor Institute for Teaching and Learning, University of Calgary. https://youtu.be/59mBo9neEgY

Penaluna, L.-A., \& Ross, R. (2022). How to talk about academic integrity so students will listen. In S. E. Eaton \& J. Christensen Hughes (Eds.), Academic integrity in Canada: An enduring and essential challenge. Springer.

Peters, M., Fontaine, S., \& Frenette, E. (2022). Teaching the teachers: To what extent do preservice teachers cheat on exams and plagiarise in their written work? In S. E. Eaton \& J. Christensen Hughes (Eds.), Academic integrity in Canada: An enduring and essential challenge. Springer.

Poitras Pratt, Y., \& Gladue, K. (2022). Re-defining academic integrity: Embracing Indigenous truths. In S. E. Eaton \& J. Christensen Hughes (Eds.), Academic integrity in Canada: An enduring and essential challenge. Springer.

Rogerson, A. M., \& Basanta, G. (2016). Peer-to-peer file sharing and academic integrity in the Internet age. In T. Bretag (Ed.), Handbook of Academic Integrity (pp. 273-285). Springer.

Rossi, S. L. (2022). Revisioning paraphrasing instruction. In S. E. Eaton \& J. Christensen Hughes (Eds.), Academic integrity in Canada: An enduring and essential challenge. Springer.

Sopcak, P., \& Hood, K. (2022). Building a culture of restorative practice and restorative responses to academic misconduct In S. E. Eaton \& J. Christensen Hughes (Eds.), Academic integrity in Canada: An enduring and essential challenge. Springer.

Stoesz, B. M. (2022). Understanding provincial and territorial academic integrity policies for elementary and secondary education in Canada. In S. E. Eaton \& J. Christensen Hughes (Eds.), Academic integrity in Canada: An enduring and essential challenge. Springer.

Teymouri, N., Boisvert, S., \& John-West, K. (2022). Promotion of academic integrity through a marketing lens for Canadian post-secondary institutions. In S. E. Eaton \& J. Christensen Hughes (Eds.), Academic integrity in Canada: An enduring and essential challenge. Springer.

Thacker, E. J., \& McKenzie, A. (2022). Using quality assurance frameworks to support an institutional culture of academic integrity at Canadian universities. In S. E. Eaton \& J. Christensen Hughes (Eds.), Academic integrity in Canada: An enduring and essential challenge. Springer. 
Watson Hamilton, J. (2022). The distinctive nature of academic integrity in graduate legal education. In S. E. Eaton \& J. Christensen Hughes (Eds.), Academic integrity in Canada: An enduring and essential challenge. Springer.

Sarah Elaine Eaton Ph.D., is an Associate Professor in the Werklund School of Education and the inaugural Educational Leader in Residence, Academic Integrity, University of Calgary. She is also the Editor-in-Chief of the International Journal for Educational Integrity and the author of Plagiarism in Higher Education: Tackling Tough Topics in Academic Integrity (Eaton, 2021b). Her research focuses on ethics and integrity in higher education and she has led numerous research teams and the local and national levels. Eaton advocates for pro-active and multi-stakeholder approaches to upholding and enacting integrity throughout the academy.

Julia Christensen Hughes Ph.D., has long advocated for ensuring the highest standards of academic integrity in higher education - in teaching, research and administrative practice. Her article, Academic Misconduct within Higher Education in Canada, with the late Don McCabe (published in 2006, in the Canadian Journal of Higher Education), received the Sheffield Award for research excellence (2007), from the Canadian Society for Studies in Higher Education. As former and founding Dean of the Gordon S. Lang School of Business and Economics (2009-2019) at the University of Guelph, Julia was a champion of business ethics, corporate social responsibility and the need for business schools to be aligned with the UN's Sustainable Development Goals (SDG's). In her new role as President of Yorkville University, Julia is looking forward to supporting and strengthening the institution's long-standing commitment to integrity.

Open Access This chapter is licensed under the terms of the Creative Commons Attribution 4.0 International License (http://creativecommons.org/licenses/by/4.0/), which permits use, sharing, adaptation, distribution and reproduction in any medium or format, as long as you give appropriate credit to the original author(s) and the source, provide a link to the Creative Commons license and indicate if changes were made.

The images or other third party material in this chapter are included in the chapter's Creative Commons license, unless indicated otherwise in a credit line to the material. If material is not included in the chapter's Creative Commons license and your intended use is not permitted by statutory regulation or exceeds the permitted use, you will need to obtain permission directly from the copyright holder.

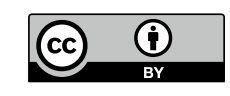

